\title{
Twisted Eulenspiegel: An Educational Approach To Role Playing In The Narrative Contexts
}

\author{
Pio Alfredo Di Tore
}

\section{Domenico D’Arienzo}

\author{
Università degli Studi di Salerno \\ Email: pditore@unisa.it, ddarienzo@unisa.it
}

\section{Doi:10.5901/mjss.2014.v5n20p1118}

\section{Abstract}

The theoretical framework of this study combines the concepts of role playing, storytelling and perspective taking in the creation of an interactive virtual environment, in order to assess and train the ability of students in primary and secondary level to take the point of view of the characters of a narrative. In order to develop this sense of "role" in an interactive virtual environment, we relied on the Vladimir Propp's work on morphology of fairy tale. With regard to the identification of literary material, we have focused attention on the cycle of stories of Till Eulenspiegel. The research path provides a virtual reconstruction of the world of Till, through interactive $3 D$ animation that represents the scenario of the tales: a medieval town in which we developed an objective view, a vision of the entire district in Third Person Camera, and a subjective view, in First Person Camera, centered on the point of view of the character. Students will, therefore, deconstruct and reconstruct the original story, basing on the answers which they give to Till Eulenspiegel, becoming in turn deuteragonists or antagonists, villains or donors, helpers or false heroes..

Keywords: role playing; digital storytelling; perspective taking; morphology of tales;

\section{Introduction}

The conceptual framework of this study combines the concepts of role playing, storytelling and perspective taking in the creation of an interactive virtual environment, in order to assess and train the ability of students in primary and secondary level to take the point of view of the characters of a story.

The role playing, in the field of teaching, is a particular type of exercise designed to give to participants the chance to play the role of "actors", for a limited period of time. It is a theatrical representation, in a broad sense, of a default situation, in which participants have the opportunity to examine their own behavior, to experiment with new attitudes, and especially, to emphasize different points of view in order to receive positive feedback.

According to Moreno, role playing consists in imitating the roles of other people, and it can be considered a behavior that naturally occurs in children (Moreno, 1934). Numerous studies, of which McNamara and Blumer offer a comprehensive review, have been conducted to evaluate the effectiveness of role playing in educational or therapeutic contexts (Mcnamara \& Blumer, 1982). Janis and Mann, had already emphasized, in 1977 how "role playing has been found an effective way to produce changes in expectations" (Janis \& Mann, 1977).

In the scientific literature, the concept of role playing was often confused with other key terms such as "simulation" and "game". In a study of 1986, Biddle (Biddle, 1986) accurately defined the concept of role playing, supporting the distinction made by Van Ments (Ments, 1983), which considered the simulation as ' a simplified reproduction of part of a real or imaginary world ' whereas the play was defined as "a structured system of competitive play that incorporates the material to be learnt"(Ments, 1983). In the definition of Van Ments, the role playing experience is distinct from simulation and game, and essentially consists of "a make-believe representation of some real-life event, carried out in order to help participants [who play a role] get better at managing the event itself" (Ments, 1983).

Furthermore, Biddle takes on the definition of McGuire \& Priestley, according to which "in role-play, participants assume a specific role, enter a simulated scenario and behave as they expect they should in the circumstances" (McGuire \& Priestley, 1981).

In 1997, Errington defined a set of characteristics in order to make effective role playing in educational contexts. For the purposes of this paper, it is of great importance to share the Errington's view in approaching the concept of role playing with perspective taking and empathy.

"Role-play provides a dynamic environment for comparing and contrasting different social and political positions or 
perspectives on an issue. The different perspectives may lead to greater empathetic understanding" (Errington, 1997).

Errington points out, referring to Richardson \& Kleiner (Richardson \& Kleiner, 1992), as role-playing in education involves a considerable effort in instructional design: "role-play is very time consuming to design, implement and evaluate" (Richardson \& Kleiner, 1992).

According to Joyce and Weil, Role playing is a teaching strategy that fits within the models of social family (Joyce, Weil, \& Calhoun, 1986).

These strategies emphasize the social nature of learning, and emphasize the cooperative behavior by stimulating the students both socially and intellectually. Role playing as a teaching strategy offers several advantages for both the teacher and the student. First, students' interest in the topic is raised. Research has shown that "the integration of experiential learning in the classroom increases interest in understanding of topic and content" (Poorman, 2002).

The affinity of role playing with drama and storytelling have been the subject of a study by Robertson \& Good , conducted on the evaluation of role playing sessions:

"Expert evaluation of the role-play sessions and resulting stories supports the view that the virtual role-play environment is particularly beneficial to children with low literacy (Robertson \& Good, 2003).

With regard to the narrative aspect, in particular, Robertson \& Good refer to the seminal work of Bruner: "The imaginative application of the narrative mode leads ... to good stories, gripping drama, believable... historical accounts. It deals with human or human-like intention and the vicissitudes and consequences that mark their course. It strives to put its timeless miracles into the particulars of experience, and to locate the experience in time and space" (Bruner, 2003)

Robertson \& Good, then mentioning Engel, support the idea that storytelling, drama and role playing share a peculiar aspect:

"we project ourselves into different possible experiences as a way of exploring who we are and who we are not. Clearly part of who we are is shaped by the people we imagine being." (Engel, 1995).

Finally, Robertson \& Good highlight how virtual environments constitute a medium that lends itself naturally to the learning activities based on storytelling, dramatization and role playing:

"Graphical virtual environments provide a new medium for collaborative drama activities. As they have become easier to develop, more researchers have chosen to investigate graphical virtual environments as a medium for role-play or story making (Robertson \& Good, 2003).

\section{Roles and Functions in Narrative Contexts}

In Italy, the effectiveness of role playing as a pedagogical method of animation has been underlined by Capranico and, more recently, by Bonaiuti, Calvani, Ranieri:

Accordig to Capranico, role playing falls within active learning methods classifiable under the term simulation. [...]In an educational context role playing combines memory with mechanisms of creativity and identification activating the motor and affective memory " (Capranico, 1997)

In the words of Bonaiuti, Calvani and Ranieri, role playing is a "strategy based on the reconstruction of a real situation (dramatization) in which students are asked to interpret social or representative roles to develop relational skills or decision-making skills" (Bonaiuti, Calvani, \& Ranieri, 2007).

As this work is based on the role as a key component of the role playing and storytelling, we believe it is appropriate to start with a precise definition of "role".

According to Hayes-Roth, a role is a class of individuals whose behaviors, relationships and interactions prototypes are known to the actors and the audience (Hayes-Roth, Van Gent, \& Huber, 1997).

In order to develop the sense of "role" in an interactive virtual environment, we relied on the Vladimir Propp's work on morphology of fairy tale, published in Russian in 1928, but largely unknown in the West until its first translation in 1958(Propp, 1966, 2010) .

One of the most fruitful development of Propp's theory affects the function of the characters in the tale. When the linguist and anthropologist called the thirty-one functions that make up the story, offering its world-famous scheme, he wanted to put the accent on what the characters do and on what they experience, rather than on their identity, including that of gender: to characterize, namely, the development of the story plot, nodal actions are carried out from time to time by the hero-protagonist and deuteragonists, by antagonists as well as by simple "characters", even outlined for a short time. The function is, for Propp, "an act of a character, defined from the point of view of its significance for the course of action". According to Propp, "functions of characters serve as stable, constant elements in a tale, independent of how and 
by whom they are fulfilled" (Propp, 2010).

Each role in a story, is associated with a set of functions. For example, the main function of the villain is the villany, or the capacity to cause significant damage to the protagonist or someone close to the protagonist. The function is carried out independently with respect to the agent, whether it be, for example, a dragon or a princess. The actions of the characters are then guided by the role that the characters play in the story. (Paiva, Machado, \& Prada, 2001)

\section{Research Methodology}

On these theoretical assumptions, the present work represents the start of preliminary communication on a research project aimed at evaluating the ability of secondary school students to take a point of view different from their own

The phases of the research path are:

1) Definition of the methodology;

2) Identification of the literary material;

3) Definition of the story world;

4) (Re)writing workshop;

5) Design and development of software environment;

6) Software testing during educational activities.

Starting from a choice made out of a fairy tale or a group of tales, then:

a) We identify the nodes on which various roles come into play (on the basis of the scheme of Propp, see table 1);

b) We hypothesize possible narrative forks, linked to characters other than the protagonist, which lead to different paths, or if you prefer, to simplex deviations (Berthoz, 2011; di tore, 2014) from the original fairy tale (see appendix B); After a preliminary work of the division of the text into sequences, useful to specify when the characters enter the story and when they make choices, we develop a flowchart (Appendix B) that highlights the choices made by a character other than the protagonist: in this scheme, you get the original sequence of the fairy tale following the arrows on the right, while the diamonds represent narrative hubs involving choices of non-protagonist characters.

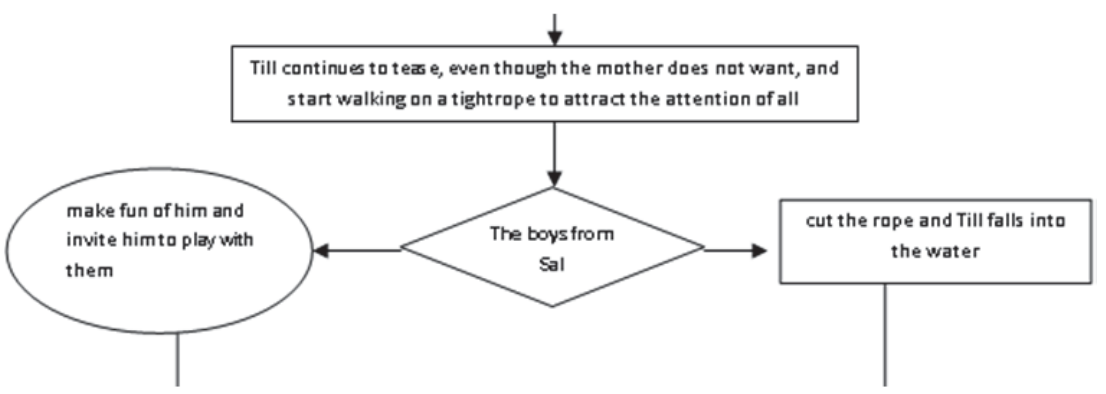

Figure 1. excerpt from the flowchart created on the stories of Till Eulenspiegel

c) We assign a role to the student and put it in front of a hub of the plot.

In this stage, we follow the classical sequence suggested by Cherif, Verma e Sommervill (Cherif, Verma, \& Somervill, 1998):

a. Preparation and explanation of the activity on the part of the teacher.

b. Preparation of students (Briefing, role assignment and nomination of observers and note taker, instructions)

c. Role-playing game.

d. Discussion after the role-play activities (cooling off, debriefing)

If student chooses the path of the original fairy tale, then he will have correctly interpreted the role and function of the character within the narrative context. 
Table 1 - broad character functions in Propp's approach

\begin{tabular}{ll}
\hline Character & Role \\
\hline Hero & Leads the narrative, usually searching for something or on some form out quest and succeeds \\
Villain & Struggle against hero \\
Donor & Prepares the hero or gives hero something to help with the quest \\
Helper & In the critical moments, supports the hero \\
False Hero & Takes credit for the hero's actions or tries to marry the princess \\
Dispatcher & Makes the lack known and sends the hero off \\
\hline
\end{tabular}

With regard to the identification of literary material, we have focused attention on a cycle of stories, those of Till Eulenspiegel, set in a well-defined historical period, the Late Middle Ages, and in a well-defined region, the central Europe.

The stories of Till Eulenspiegel are not common heritage of Italian students, and thus represent an innovation that can produce not obvious answers and behaviors.

\section{The Story World}

The definition of the story world was based on considerations of Klastrup and Tosca, according to which a needed condition for the creation of a believable fictional universe is the complete description of each element of the story, even that seemingly insignificant, which bears his "personal history" within the main storyline (L. Klastrup \& S. P. Tosca, 2004).

Klastrup and Tosca (2004) define the story world as "the structure within which all of the concepts, objects, entities, and relationships needed to construct a narrative exist"(L. Klastrup \& S. Tosca, 2004) and identify three main components:

- Mythos, that is to establish the conflicts and the battles of the world, the background of all the personal stories;

- Topos, that is the space-time coordinates of the universe;

- Ethos, that is morals or behavior code which characters of the world should follow.

The next step of the research path provides a virtual reconstruction of the world of Till, through interactive 3D animation that will represent the scenario of the tales: a medieval town in which we developed an objective view, a vision of the entire district in Third Person Camera, and a subjective view, in First Person Camera, centered on the point of view of the character (Mangione et al., 2013; Raiola\&Di Tore, 2012). Students will, therefore, deconstruct and reconstruct the original story, basing on the answers which they give to Till, when they cross his way, becoming in turn deuteragonists and antagonists, villains or donors, helpers or false heroes.

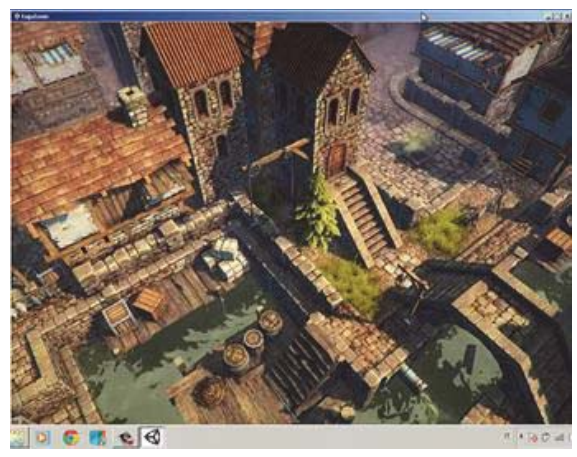

Figure 2 - Till town, Third Person Camera 


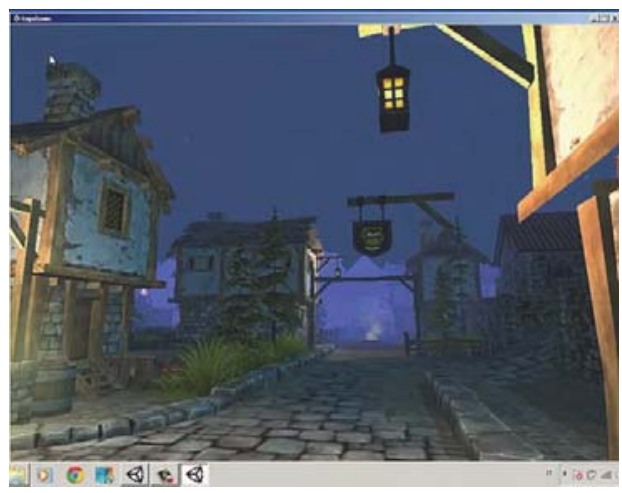

Figure 3 - Till town, First Person Camera

\section{Twisting Eulenspiegel}

The workshop stage was set up with the collaboration of the Alfonso Gatto Foundation, for a long time promoting writing workshops in schools.

At this stage, students are asked to invent alternate paths within the selected stories, putting themselves in the role of one of the characters encountered by Till and taking on the character point of view, in order to reorganize the narrative material and create new stories centered on the identified character.

In 1511-12 was published in Strasbourg, the first edition of the anonymous Volksbuch Von Eulenspiegel, the beginning of great literary and popular fortune of Till.

His name is Dyl Ulenspiegel or Till Eulenspiegel, which literally means "mirror of the owl," or "mirror of fools": he is a wanderer boy, the son of poor peasants of Lower Saxony, a particularly depressed area at time of his adventures.

Till experiences a thousand works, but its true mission is one: to live as a vagabond, experiencing the world around him, and scoring a series of " prankster shots ", whose spectrum ranges from the humorous and harmless banter to the real dirty trick.

The Adventures of Till recall to mind classic notes the "feeling of childhood" in late medieval Europe by Philippe Aries (Aries, 1971), which depicts in his paintings, "mature" children.

His goal is absolutely a "democratic" goal: to strike anyone who has the fortune to run into him, aristocrats and petty bourgeoisie, artisans and self-proclaimed "full of wisdom" university teachers, up to the high priests and kings, and even the pope.

Because he understood that true freedom is one of the foolish and crazy fake.

In this perspective, Till is not far, either temporally, from Shakespearean fool. The character of Till is the prankster capable of laying bare the contradictions, the weaknesses, the injustice of human society, certainly not with the intent to subvert the established order but with the far more realistic and practicable aim to erect a strenuous opposition to bullying and harassment, widespread in all ganglia of the medieval social structure.

His method is simple, and so brilliant: Till, who is a farmer, does not understand (or pretends not to understand) the metaphorical, figurative value of language. His prerogative is simply the will to survive. At times, he gives mocker, becometh mocked; he always takes his revenge, excruciatingly sometimes, sometimes with unexpected elegance: there is no moral final, anything to be learned for future reference.

The stories of Till are ninety-six and range from a few lines to a maximum of four pages. In a medieval world, the biographical frame of Till appears to be considerable, inscribing the adventures of the wandering boy between his birth and his death (the last story, in fact, is the epitaph affixed on his tomb).

Between these two extremes, there are childcare and early adventures, adolescence and maturity, the old age that leads to extreme misadventures and pranks before death.

The never schematic simplicity and the inner coherence of the episodes of this cycle; the always unambiguous questions and the answers of all the characters; the well-defined characters capable of standing out clearly, as well as the easily recognizable and never equivocal behaviors: these are the characteristics that have made us lean towards our choice. It seemed that this cyclic linearity, combined with a sort of comical repetition compulsion of the protagonist, could respond better to the overall design of the role playing project we go pursuing. If it is true that most of the stories is 
irreproducible, the selection that we are working on allows us to tie together, through simple syntactic constructs or timestamps, the gaming, and perspective-taking experience that we want to encourage in students. At the same time, we will rebuild the entire span of the adventures experienced by Till, all of them back within the fold of his childhood and early adolescence, so as to achieve the required identification on the part of the young participants, even if the original text, however, refers to a different and more mature age of Till.

\section{References}

Berthoz, A. (2011). La semplessità: Codice.

Biddle, B. J. (1986). Recent development in role theory. Annual review of sociology, 67-92.

Bonaiuti, G., Calvani, A., \& Ranieri, M. (2007). Fondamenti di didattica. Teoria e prassi dei dispositivi formativi. Carocci.

Bruner, J. S. (2003). Making stories: Law, literature, life: Harvard University Press.

Capranico, S. (1997). Role playing: manuale a uso di formatori e insegnanti: Raffaello Cortina.

Cherif, A. H., Verma, S., \& Somervill, C. (1998). From the Los Angeles zoo to the classroom: Transforming real cases via role-play into productive learning activities. The American Biology Teacher, 613-617.

Di Tore, P. A. (2014). Perception Of Space, Empathy And CognitiveProcesses: Design Of A Video Game For TheMeasurement Of Perspective Taking Skills. International Journal of Emerging Technologies in Learning (iJET), 9(7), 6. doi: http://dx.doi.org/ 10.3991/ijet.v9i7.3718.

Engel, S. (1995). The stories children tell: Making sense of the narratives of childhood: Macmillan.

Errington, E. (1997). Role-play: HERDSA.

Hayes-Roth, B., Van Gent, R., \& Huber, D. (1997). Acting in character. Springer.

Janis, I. L., \& Mann, L. (1977). Decision making: A psychological analysis of conflict, choice, and commitment: Free Press.

Joyce, B. R., Weil, M., \& Calhoun, E. (1986). Models of teaching (Vol. 499): Prentice-Hall Englewood Cliffs, NJ.

Klastrup, L., \& Tosca, S. (2004). Transmedial worlds-rethinking cyberworld design. Paper presented at the Cyberworlds, 2004 International Conference on.

Klastrup, L., \& Tosca, S. P. (2004). Transmedial Worlds-Rethinking Cyberworld Design. Paper presented at the CW.

Mangione, G. R., Discepolo, T., Di Tore, P. A., Di Tore, S., Cozzarelli, C., \& Corona, F. (2013, Jul). Measuring Empathy to Support Learning Design and Narrative Game: A Phenomenological Approach. Paper presented at the 2013 Seventh International Conference on Complex, Intelligent, and Software Intensive Systems.

McGuire, J., \& Priestley, P. (1981). Life After School: a Social Skills Curriculum. oxford: Pergamon Press.

Mcnamara, J. R., \& Blumer, C. A. (1982). Role Playing to Assess Social Competence Ecological Validity Considerations. Behavior Modification, 6(4), 519-549.

Ments, M. (1983). The effective use of role-play: A handbook for teachers and trainers. NP Cogan Page, London.

Moreno, J. L. (1934). Who shall survive?: A new approach to the problem of human interrelations.

Paiva, A., Machado, I., \& Prada, R. (2001). Heroes, villians, magicians,.... dramatis personae in a virtual story creation environment. Paper presented at the Proceedings of the 6th international conference on Intelligent user interfaces.

Poorman, P. B. (2002). Biography and role playing: Fostering empathy in abnormal psychology. Teaching of Psychology, 29(1), 32-36.

Propp, V. (1966). Morfologia della fiaba: Einaudi.

Propp, V. (2010). Morphology of the Folktale: Revised and Edited with Preface by Louis A. Wagner, Introduction by Alan Dundes (Vol. 9): University of Texas Press.

Raiola, G., Di Tore, PA. (2012). Non-Verbal Communication and Volleyball: A New Way to Approach the Phenomenon. Mediterranean Journal of Social Sciences, 347.

Richardson, J. D., \& Kleiner, B. H. (1992). The relevant effectiveness of different training and development methodologies. Management Research News, 15(10), 23-26.

Robertson, J., \& Good, J. (2003). Using a collaborative virtual role-play environment to foster characterisation in stories.

\section{Appendix A}

\section{List of Selected Tales}

Reference edition is Till Eulenspiegel, edited by Luigi Tacconelli, Roma, Salerno Editrice, 1979

I storia Narra come Till nacque e in un giorno fu battezzato tre volte e chi furono i suoi padrini.

II storia Narra come tutti i contadini e le contadine si lamentavano del fanciullo. E dicevano che era un discolo e un briccone, e come egli cavalcava in groppa ad un cavallo dietro a suo padre e tacitamente faceva mirare alla gente il culo.

III storia Narra come Claus, padre di Till, si trasferì sul fiume Sal. Qui egli morì e Till imparò a camminare sulla fune.

IV storia Narra come Till con le chiacchiere ottenne che i ragazzi si togliessero dai piedi duecento paia di scarpe e fece in modo che alla fine vecchi e giovani si accapigliassero.

V storia Narra come la mamma di Till voleva esortarlo ad apprendere un mestiere e in ciò ella voleva aiutarlo.

VII storia Narra come Till con altri ragazzi mangiò la zuppa di brodo, di salsiccia e di pan bianco e come egli ne dovette mangiare oltre misura e fu battuto. 
VIII storia Narra come Till fece sì che i polli dell'avaro contadino abboccassero all'esca, tirandosi a vicenda di qua e di là.

IX storia Narra come Till si infilò in un'arnia e come nella notte due vennero a furare l'arnia e come egli fece che i due s'azzuffassero e lasciassero cadere l'arnia.

$X$ storia Narra come Till diventò garzone di corte e come il suo cavaliere predone gli insegnò che ogni volta che trovasse l'erba chenepa si dovesse cagare sopra. E come egli allora cagò sulla senepa, pensando che chenepa e senepa fossero la stessa cosa.

$X I$ storia Narra come Till ando a servizio da un pievano e come gli mangiò dallo spiedo i polli arrostiti.

XXII storia Narra come Till andò a servizio del conte di Anhalt come trombettiere della torre di guardia e come egli non suonava l'allarme quando i nemici si avvicinavano ma suonava quando non c'era nemmeno un nemico.

XXVII storia Narra come Till dipinse il langravio di Essen dandogli ad intendere che chi fosse figlio illegittimo non avrebbe potuto scorgere il dipinto. XXVIII storia Narra come Till a Praga all'università tenne con gli studenti una disputa e la superò egregiamente.

XXXII storia Narra come Till in Norimberga svegliò i guardiani della città i quali lo inseguirono su un ponticello e caddero in acqua.

XXXVI storia Narra come Till in Quedlinburg comprò polli alla contadina, lasciò in pegno per il denaro il suo gallo.

XXXVII storia Narra come il pievano di Egelssheim mangiò a Till una salsiccia che poi gli fece male.

XLI storia Narra come Till ad un fabbro e a sua moglie, al garzone e alla fante, disse ad ognuno una verità fuori, davanti alla casa.

LVII storia Narra come Till, in Lubecca, ingannò l'oste quando gli diede un boccale d'acqua per un boccale di vino.

LVIII storia Narra come in Lubecca volevano impiccare Till e come egli se la scampò con un'astuta cattiveria.

LIX storia Narra come Till in Helmstet si fece fare una grossa borsa.

$L X$ storia Narra come Till ad un macellaio truffò un arrosto.

LXI storia Narra come Till ad un macellaio truffò ancora una volta un arrosto.

LXII storia Narra come Till a Dresda diventò garzone di falegname e non guadagnò molta gratitudine.

LXIV storia Narra come Till andò a servizio da un mercante come cuoco e fuochista e là si comportò molto bricconescamente.

LXVII storia Narra come Till fu burlato da una vecchia contadina, quando egli ebbe perduto la sua borsa.

LXXVIII storia Narra come Till spaventò il locandiere con un lupo che questi aveva promesso di catturare.

LXXXI storia Narra come Till partì da Rostock.

LXXXII storia Narra come Till scuoiò un cane e diede la pelle alla locandiera come pagamento poiché esso aveva mangiato con lui.

XCIII storia Narra come Till distribuì i suoi beni in tre parti: una parte ai suoi amici, una parte al consiglio di Mollen, una parte al pievano di là.

$X C I V$ storia Narra come Till morì, e i porci durante la veglia funebre rovesciarono la sua bara così egli cadde giù.

XCV storia Narra come Till fu sepolto, poiché egli non voleva essere sepolto né da religiosi, né da secolari, bensì da beghine.

XCVI storia Narra come l'epitaffio e l'iscrizione sepolcrale di Till stanno scolpiti sulla sua tomba.

\section{Appendix B}

This chart brings together the top five stories of the Till Eulenspiegel cycle, useful, due to their simplicity, to illustrate the plot development.

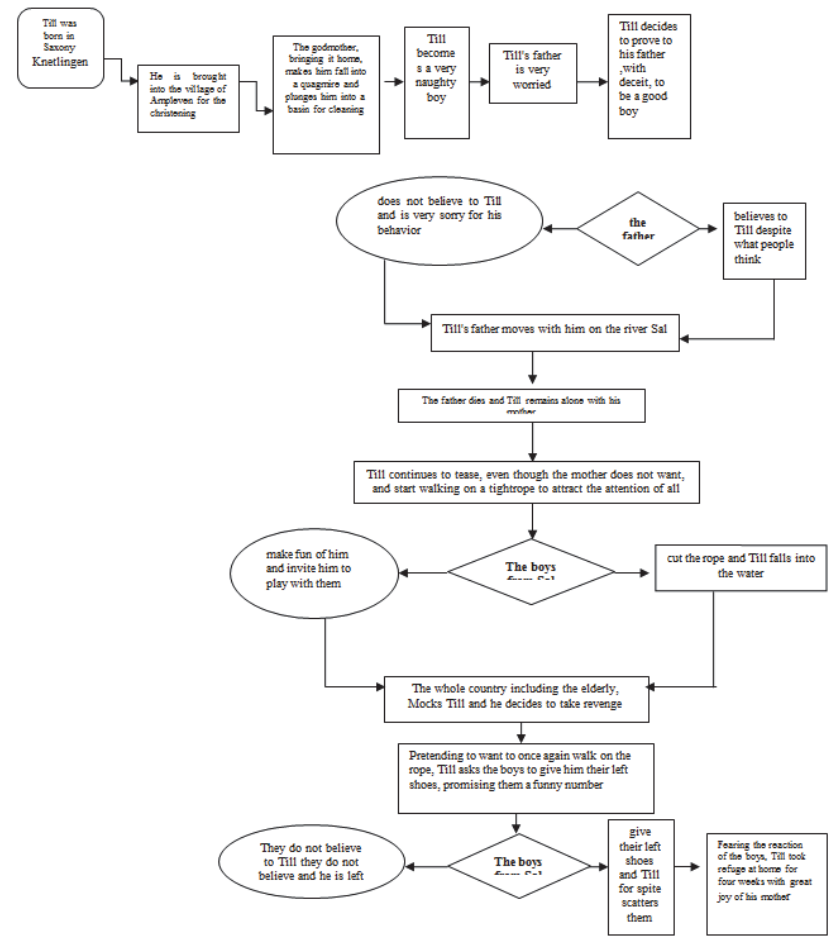

